\title{
АНАЛИЗ ИЗМЕНЕНИЙ В ИК-СПЕКТРАХ СЕМЯН ОЗИМОЙ РЖИ, ПОДВЕРГНУТЫХ РАЗЛИЧНЫМ ВИДАМ ВЛАГОТЕПЛОВОЙ ОБРАБОТКИ
}

\author{
(c) И.Т. Бикчантаев ${ }^{1}$, Ш.К. Шакиров ${ }^{1}$, Э.М. Ягун ${ }^{2 *}$, Р.Г. Яхин ${ }^{2}$ \\ ${ }^{1}$ Татарский научно-исследовательский институт сельского хозяйства, \\ Оренбургский тракт, 48, Казань, 420059 (Россия) \\ ${ }^{2}$ Казанский государственный архитектурно-строительный университет, \\ ул. Зеленая, 1, Казань, 420043 (Россия), e-mail: yagund1962@mail.ru
}

\begin{abstract}
Методом Фурье ИК-спектроскопии в средней области проведен качественный анализ процессов, происходящих при различных видах гидротермической обработки озимой ржи: экструдировании, ферментировании, варке, обжаривании, проводимых с целью повышения кормовой ценности зерна. Выявлены полосы поглощения, по которым можно судить о влажности зерна, а также о содержании в нем белка, клетчатки и крахмала. Установлено, что в зависимости от вида обработки изменения в ИК-спектрах связаны с превращениями либо белковых, либо углеводных макромолекул. Показано, что при ферментировании всех образцов происходит гидролиз макромолекул углеводов (прежде всего крахмала) и превращение этих соединений в углеводы с меньшей молекулярной массой. Экструдирование, варка и обжаривание ржи приводит к денатурация растительного белка, а углеводная часть остается в целом неизменной. Однако при любом варианте влаготепловой обработки зерна в нем происходят сложные процессы биохимической природы, результатом которых является изменение биохимических и физических свойств зерна и его питательной ценности.

Ключевые слова: озимая рожь, влаготепловая обработка, растительный белок, крахмал, метод Фурье ИКспектроскопии.
\end{abstract}

\section{Введение}

В земледелии ряда стран Северной, Центральной и Восточной Европы озимой ржи уделяется особое внимание. Известно, что эта культура предъявляет самые низкие требования к плодородию почвы, условиям минерального питания и защиты растений, т.е. позволяет получать экологически безопасную и дешевую продукцию. Ни одна зерновая культура не может сравниться с рожью по способности формировать высокие урожаи в неблагоприятные и даже экстремальные по метеоусловиям годы, а также использовать потенциал низкоплодородных почв [1]. Озимую рожь возделывают в основном для пищевых целей и только 8-12\% валового сбора зерна используют в производстве комбикормов. Это связано с наличием в его составе таких антипитательных веществ, как фитиновая кислота, пентозаны, пектин, $\beta$-глюканы, танины, ингибиторы трипсина и химотрипсина, 5-алкилрезорцины. Попадая в организм, они нарушают процессы пищеварения у животных, что ведет к снижению их продуктивности [2]. Общее количество некрахмали-

Бикчантаев Ирек Тагирович - кандидат биологических наук, старший научный сотрудник, e-mail: yagund1962@mail.ru

Шакиров Шамиль Касымович - руководитель НТЦ животноводства, доктор сельскохозяйственных наук, профессор, e-mail: yagund1962@mail.ru

Ягунд Эдуард Михайлович - кандидат химических наук, доцент кафедры физики, электротехники и автоматики, e-mail: yagund1962@mail.ru

Яхин Рашит Гарафутдинович - заведующий кафедрой физики, электротехники и автоматики, доктор технических наук, профессор, e-mail: yagund1962@mail.ru стых полисахаридов в зерне ржи достигает 17,5\%, поэтому использование ее в кормлении ограничено на уровне $40 \%$ у жвачных животных, свиней - 20\% и птицы - 5-7\%. В то же время следует отметить, что озимая рожь по сравнению с другими злаковыми культурами имеет довольно высокую концентрацию легкоусвояемых сахаров (более чем в 2 раза). Поэтому возникает потребность в технологиях, которые позволили бы существенно повысить процент содержания ржи в рационах кормления сельскохозяйственных животных [3-5].

\footnotetext{
* Автор, с которым следует вести переписку.
} 
Наиболее действенными способами снижения антипитательных веществ и повышения содержания сахаров является селекция озимой ржи на качество, а также эффективные технологические приемы: использование ферментов, обжаривание, влаготепловая и барометрическая обработка, или экструдирование. Все это способствует повышению переваримости ржи, а значит, ведет к повышению продуктивности животных, увеличению содержания ржи в комбикормах и снижению расходов кормов [4].

Согласно литературным данным [6], рожь содержит около 11-12\% протеина, 70\% безазотистых экстрактивных веществ, примерно по 2\% клетчатки, жира, золы. Процессы, связанные с влаготепловой обработкой зерновых кормов для повышения их кормовой ценности, основаны на целенаправленном преобразовании питательных веществ в корме от сложных биополимеров к более простым. В процессе обработки происходит значительное расщепление крахмала и отчасти клетчатки, увеличивается содержание сахаров, а белки теряют свою четвертичную структуру [7].

Классический химический анализ различных органических соединений занимает значительное время, требует применения дорогостоящих и часто токсичных реактивов, высокой квалификации персонала и сложного оборудования. Альтернативным эффективным способом химическому анализу является метод инфракрасной спектроскопии. Этот метод позволяет определить химический состав молекул, сделать выводы о их структуре, а также судить о величине и характере меж- и внутримолекулярных взаимодействий. При анализе качества продукции и сырья сельскохозяйственной и пищевой промышленности, фармацевтических препаратов, продуктов нефтепереработки наиболее широко применяется метод ближней инфракрасной спектроскопии $[8,9]$. Для этой области разработаны стандартные методы анализа и созданы специализированные спектрофотометры, успешно и с высокой точностью позволяющие определять химический состав, влажность и другие важнейшие характеристики продуктов растениеводства [10]. Изучению продуктов сельскохозяйственного производства в средней ИК-области посвящено гораздо меньшее число работ. Это объясняется тем, что основные компоненты этих объектов (белки, углеводы и жиры) имеют сложное химическое строение, а интерпретация их спектров в средней области часто затруднена.

В данной работе исследовалась возможность применения метода Фурье ИК-спектроскопии в средней области для изучения изменений, происходящих в ряде образцов семян озимой ржи при различных способах их влаготепловой обработки.

\section{Методика эксперимента}

Для экструдирования зерна использовали пресс-экструдер ПЭ-1 (Пенза, Россия). Сущность экструдирования заключается в том, что зерно подвергается кратковременному, но очень интенсивному механическому и барометрическому воздействию за счет высокой температуры $\left(110-135^{\circ} \mathrm{C}\right)$, давления (примерно 25 атм.) и сдвиговых усилий в винтовых рабочих органах экструдера. За счет резкого падения давления при выходе разогретой зерновой массы происходит значительное увеличение объема экструдата, что делает его более усвояемым для организма животных по сравнению с нативным материалом. При этом в экструдате сохраняются все биологически активные вещества и уничтожаются бактерии и плесневые грибки.

При варке зерно засыпают в емкость из нержавеющей стали, заливают водой комнатной температуры из расчета на одну объемную часть зерна три объемные части воды, доводят до кипения и кипятят при перемешивании до полного выпаривания воды.

При поджаривании зерна его сначала смачивают водой для набухания, после чего насыпают на металлический лист тонким слоем и нагревают при постоянном перемешивании до светло-коричневого цвета.

Технология ферментативной обработки зерна с помощью ферментных препаратов заключается в следующем: в емкость из нержавеющей стали заливают 3 объемные части горячей воды $\left(80-90{ }^{\circ} \mathrm{C}\right)$ и засыпают одну объемную часть зерносмеси. Затем добавляют фермент в дозе $0,1 \%$ от массы зерна и тщательно перемешивают, закрывают крышкой. Длительность обработки составляет 2-3 ч.

Регистрация ИК-спектров производилась на Фурье ИК-спектрофотометре фирмы Perkin-Elmer, модель Spectrum 65, с помощью приставки HПВО Miracle ATR (кристалл ZnSe) в области 4000-650 см-1, как правило, при 20 сканах. Запись и вычитание фонового спектра производилась автоматически. Высушенные зерна ржи, подвергнутые различным видам обработки, первоначально измельчались в вибромельнице в течение 5 мин до частиц микронного размера, после чего образовавшийся порошок (по сути, мука) прижимался к кристаллу НПВО специальным прижимом, входящим в комплект приставки. После регистрации 
автоматически осуществлялась НПВО-коррекция и сохранение спектра. ИК-спектры обработанных образцов сравнивались со спектром контрольного образца, не подвергавшегося обработке. При этом изменение интенсивности характеристических пиков оценивалось по методике [11] относительно полосы внутреннего стандарта, за который был принят пик на частоте около $857 \mathrm{~cm}^{-1}$, соответствующий валентным колебаниям глюкопиранозных колец целлюлозы.

\section{Обсуждение результатов}

По современным представлениям [4] зерно рассматривается как сложная биологическая система, состоящая из биополимеров белковой, жировой и углеводной природы, с большим числом внутри- и межмолекулярных связей. Наиболее полно высокомолекулярные углеводы растительной природы изучены методом ИКС в монографиях Р.Г. Жбанкова $[12,13]$, а также в ряде других работ [14-19].

На рисунке 1 представлен ИК-спектр необработанных зерен ржи (контрольный образец). Как видим, в спектре присутствуют характеристические полосы различной интенсивности на следующих частотах: широкая полоса с максимумом при $3287 \mathrm{~cm}^{-1}$ - накладывающиеся валентные колебания групп ОН и NH, ассоциированных Н-связью; 2925-2854 см с $^{-1}$ валентные колебания метильных и метиленовых групп; $1742 \mathrm{~cm}^{-1}$ - полоса Амид I, отвечающая за валентные колебания карбонильных групп $\mathrm{C}=\mathrm{O} ; 1646 \mathrm{~cm}^{-1}-$ деформационные колебания молекул воды, адсорбированной зерном; $1546 \mathrm{~cm}^{-1}$ - полоса Амид II, отвечающая за деформационные колебания групп NH, входящих в структуру белков; наиболее интенсивный пик на частоте 1014 см$^{-1}$, расщепленный на ряд более слабых полос при 1150, 1076 и 926 см$^{-1}$ соответствующий смешанным валентным и деформационным колебаниям связей С-О и С-С скелета макромолекулы и пиранозных циклов, являющихся основными элементами структуры целлюлозы и крахмала [20]. Указанные пики являются характеристическими и наиболее информативными при анализе ИК-спектров изученных образцов.

На рисунке 2 для сравнения с контрольным образцом (кривая 1) приведены ИК-спектры экструдата (2), вареной (3) и жареной (4) ржи. Из приведенных спектров видно, что различий в области валентных колебаний $\mathrm{CH}_{2}$ и $\mathrm{CH}$-групп практически не наблюдается, однако пик $1646 \mathrm{~cm}^{-1}$, отвечающий колебаниям адсорбированной зерном воды, слабее в спектрах 2, 3 и 4. Отметим, что несколько ниже и интенсивность полосы валентных колебаний $v(\mathrm{OH})$ при $3287 \mathrm{~cm}^{-1}$. Это означает, что обработанные образцы имеют меньшую влажность по сравнению с контрольным образцом, что объясняется процедурой сушки зерна после каждого из видов обработки. Интенсивность наиболее сильной полосы при 1014 см$^{-1}$, отвечающей углеводистой составляющей изученных образцов, практически одинакова во всех приведенных на рисунке 2 спектрах, причем неизменность интенсивности этой полосы подтверждается равенством интенсивности полосы внутреннего стандарта при $857 \mathrm{~cm}^{-1}$. Таким образом, каких-либо существенных процессов, связанных с расщеплением макромолекул полисахаридов (крахмала и целлюлозы), при данных видах обработки, по-видимому, не происходит. В то же время в спектрах обработанных образцов наблюдаются заметное уменьшение пика $1546 \mathrm{~cm}^{-1}$, отвечающего деформационным колебаниям групп NH белков, и рост интенсивности полосы $1742 \mathrm{~cm}^{-1}$ сложноэфирных групп. Наиболее заметно это проявляется для образца обжаренного зерна (рис. 2, кривая 4). Указанные изменения, по-видимому, свидетельствуют о процессах деструкции белковых макромолекул при данных видах обработки, связанных с этерификацией (образованием сложноэфирных групп). Эти процессы подробно изучены химическими и физическими методами анализа, в частности, с применением стандартного метода Кьельдаля [21] определения содержания белка и описаны в монографиях [3, 4]. Можно предположить, что частичная денатурации растительного белка положительно сказывается на кормовой ценности зерна, так как известно [3], что ценность протеина корма определяется не только аминокислотным составом, но и степенью дисперсности белков, т.е. молекулярно-массовым распределением их макромолекул.

На рисунке 3 приведены ИК-спектры контрольного образца (кривая 1) в сравнении со спектрами ржи, подвергнутой воздействию различных ферментных препаратов: НИСТ-1 (кривая 2), НИСТ-2 (кривая 3) и препарата Биоксил (кривая 4). Влажность всех обработанных образцов также несколько ниже, чем в контрольном, о чем можно судить по меньшей интенсивности пика $1646 \mathrm{~cm}^{-1}$ и полосы валентных колебаний ОН-групп при $3287 \mathrm{~cm}^{-1}$, что также объясняется процедурой сушки после обработки образцов. 


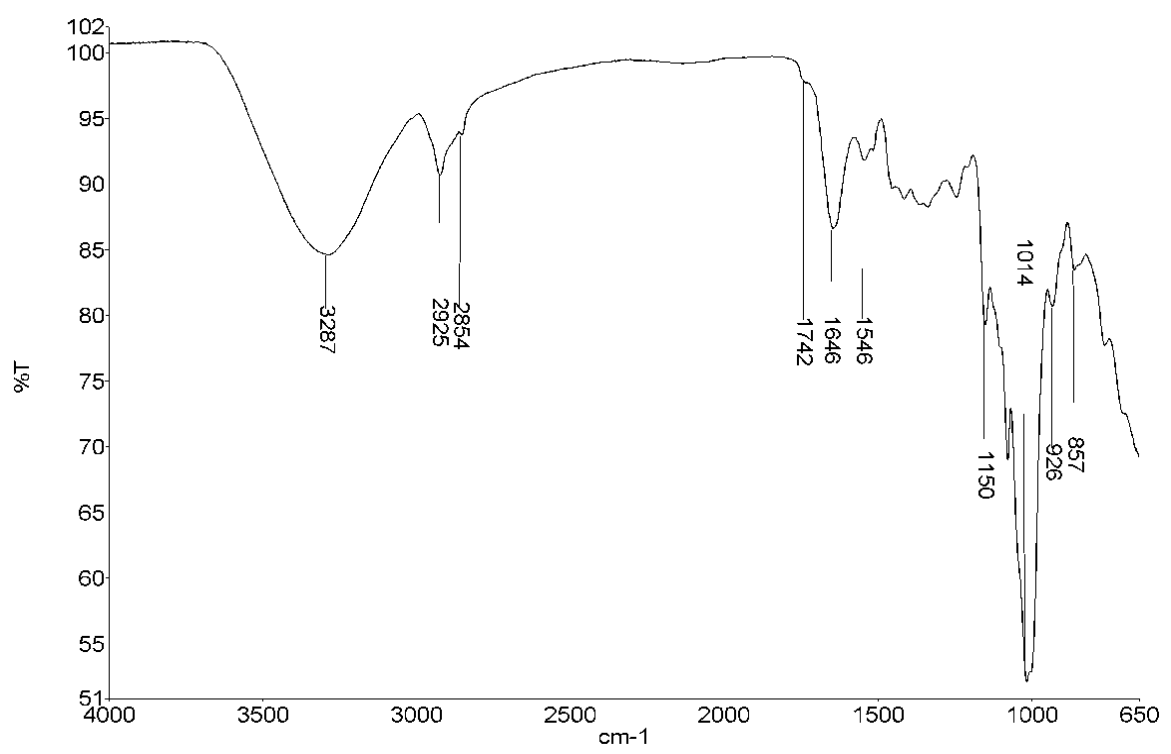

Рис. 1. ИК-спектр контрольного (нативного) образца озимой ржи

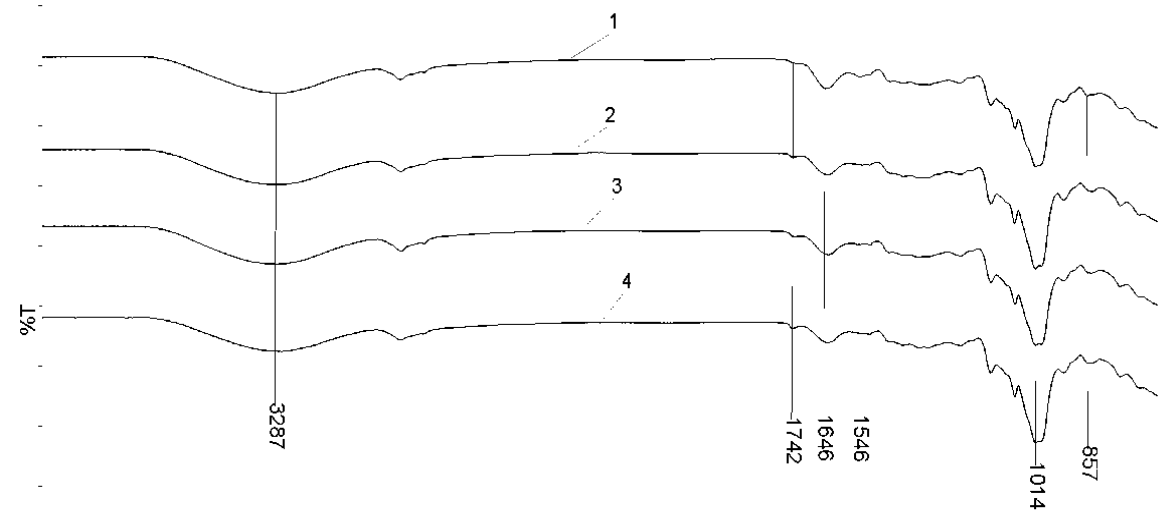

$\begin{array}{llllllll}4000 & 3500 & 3000 & 2500 & & & \\ \mathrm{~cm}-1 & 2000 & 1500 & 1000 & 650\end{array}$

Рис. 2. ИК-спектры контрольного образца (1), экструдата (2), вареной (3) и жареной (4) ржи

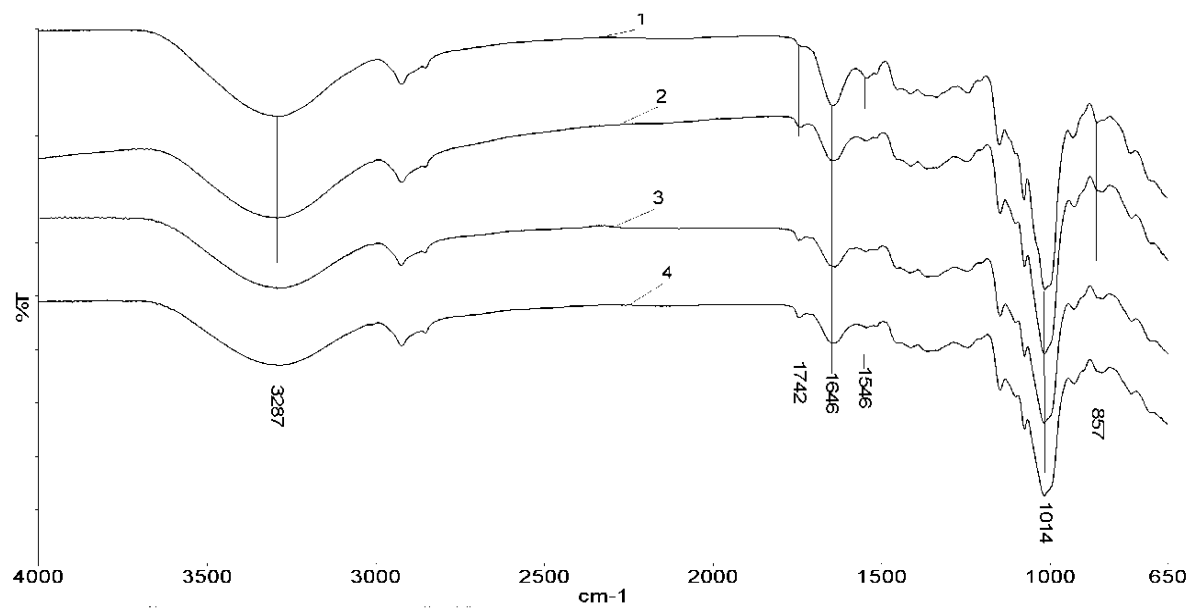

Рис. 3. ИК-спектры контрольного образца (1), ферментированного НИСТ-1 (2), НИСТ-2 (3) и препаратом Биоксил (4) 
Кроме того, обращает на себя внимание тот факт, что интенсивность полосы Амид II при $1546 \mathrm{~cm}^{-1}$ в ферментированных препаратах изменятся незначительно, однако существенно уменьшается интенсивность пика $1014 \mathrm{~cm}^{-1}$, отвечающего углеводистой составляющей биомассы зерна, при практически неизменной интенсивности полосы внутреннего стандарта при $857 \mathrm{~cm}^{-1}$. Полученные результаты позволяют сделать вывод, что при ферментировании наблюдается главным образом не денатурация растительного белка, как в предыдущем случае, а изменение свойств углеводов зерна, и прежде всего основного их представителя - крахмала. Этот результат хорошо коррелирует с данными, описанными в монографии [4] с применением классических химических методов анализа. Согласно [4], при ферментной обработке вследствие деструкции макромолекул крахмала происходит образование различных декстринов и иных водорастворимых веществ, причем содержание декстринов может увеличиться от 3 до 18 раз. В итоге конечным продуктом расщепления крахмала является мальтоза, а затем и моносахара. Расщепление макромолекул целлюлозы и крахмала на углеводы меньшей молекулярной массы существенно повышает доступность этих углеводов ферментам животных, и поэтому их ассимиляция повышается, что весьма благоприятно отражается на пищевой ценности зерна.

Таким образом, при любом варианте влаготепловой обработки зерна в нем происходят сложные процессы биохимической природы, результатом которых является изменение биохимических и физических свойств зерна и его питательной ценности как компонента комбикормов.

\section{Bblводы}

1. Методом Фурье ИК-спектроскопии в средней области изучены образцы кормовой ржи и выявлены характеристические полосы поглощения, по которым можно судить о влажности образцов, содержании в них растительного белка, целлюлозы и крахмала.

2. Установлено, что при ферментировании всех образцов происходит существенное уменьшение интегральной интенсивности пика $1014 \mathrm{~cm}^{-1}$, отвечающего колебаниям связей С-С и С-О, входящих в состав скелета макромолекул углеводов (прежде всего крахмала). Это связано, видимо, с гидролизом высокомолекулярных углеводов при ферментировании и превращением этих соединений в углеводы с меньшей молекулярной массой (декстрины), обладающие большей доступностью для организмов животных.

3. В образцах экструдата, вареной и жареной ржи отмечается заметное уменьшение интенсивности полосы Амид II, отвечающей деформационным колебаниям групп NH белковых молекул. По-видимому, при этих видах обработки происходит деструкция именно белковых молекул, а углеводная часть остается в целом неизменной.

Полученные выводы не только хорошо коррелируют с результатами, описанными в монографиях [3, 4], в которых анализ компонентов комбикормов проводится стандартными химическими методами, в частности, известным методом Кьельдаля, но и дополняют их, так как в литературе практически отсутствуют данные по изучению компонентов зерна в средней ИК-области. Результаты могут представлять интерес для специалистов в области переработки зерна, а также производства и контроля качества комбикормов.

\section{Список литературы}

1. Сысуев В.А. Комплексные научные исследования по озимой ржи - важнейшей национальной и стратегической культуре в зерновой структуре РФ // Достижения науки и техники в АПК. 2013. №6. С. 8-11.

2. Fitsev A.I., Kosolapov V.M. Zootechnical assessment of the use of rye in the diets of farm animals // Foodproduction. 2007. N1. Pp. 27-30.

3. Таранов М.Т., Сабиров А.Х. Биохимия кормов. М., 1987. 224 с.

4. Афанасьев В.А. Теория и практика специальной обработки зерновых компонентов в технологии комбикормов. Воронеж, 2002. $296 \mathrm{c}$.

5. Овсянников А.И. Основы опытного дела в животноводстве. М., 1976. 304 с.

6. Калашников А.П. Нормы и рационы кормления сельскохозяйственных животных: справочное пособие. М., 2003. $456 \mathrm{c}$.

7. Лень Т.М. Голозерный овес в рационах // Животноводство. 2005. №7. С. 23-29.

8. Крищенко В.П. Ближняя инфракрасная спектроскопия. М., 1997. 638 с.

9. Моренко В.В. Хижан Е.И., Хижан А.И., Николаевский А.Н. Использование ближней инфракрасной спектроскопии для анализа пищевых продуктов // Вестник Донецкого национального университета. Сер. А. 2011 . №2. C. $120-123$. 
10. Оборудование группы компаний «Люмекс» для лабораторий. Комплексное решение задач по контролю качества продукции и сырья // Масложировая индустрия 2010: доклады 10-й Международной конференции. СПб., 2010. С. 96-98.

11. Котенева И.В., Сидоров В.И., Котлярова И.А. Анализ модифицированной целлюлозы методом ИКспектроскопии // Химия растительного сырья. 2011. №1. С. 21-24.

12. Жбанков Р.Г. Инфракрасные спектры и структура углеводов. Минск, 1972. 298 с.

13. Жбанков Р.Г. Инфракрасные спектры целлюлозы и ее производных. Минск, 1964. 108 с.

14. Гусев С.С., Сунь Тун, Ермоленко И.Н., Роговин 3.А. Исследование строения эфиров целлюлозы с алифатическими аминокислотами и привитых сополимеров целлюлозы методами инфракрасной спектроскопии // Высокомолекулярные соединения. 1961. Т. 3. №11. С. 1684-1687.

15. Гасанова Е.С., Мязин Н.Г., Фоминых Т.О. Изучение системы почва-растение на примере топинамбура методом ИК-спектроскопии // Вестник Воронежского государственного аграрного университета. Агрономические науки. 2014. №1-2. С. 14-19.

16. Мухамадеева Р.М., Жбанков Р.Г., Сопин В.Ф., Марченко Г.Н. Низкочастотная ИК-спектроскопия в исследовании структуры целлюлозы и нитратов целлюлозы // Успехи химии. 1993. Т. 62. №4. С. 351-364.

17. Королевич М.В., Кириллова С.Г., Пиоттух-Пелецкий В.Н., Андрианов В.М. Интерпретация ИК-спектров эпоксисахаридов на основе теоретического расчета частот и интенсивностей нормальных колебаний // Журнал структурной химии. 2009. Т. 50. №1. С. 47-57.

18. Геньш К.В., Колосов П.В., Базарнова Н.Г. Качественный анализ нитратов целлюлозы методом Фурье ИКспектроскопии // Химия растительного сырья. 2010. №1. С. 63-66.

19. Сивчик В.В., Жбанков Р.Г. Исследование колебательных спектров D-глюкозы и ряда моносахаридов // Журнал прикладной спектроскопии. 1978. Т. 28. №6. С. 1038-1045.

20. Энциклопедия полимеров. М., 1977. Т. 3. С. 853-860.

21. ГОСТ 17444-76. Реактивы. Методы определения основного вещества азотсодержащих органических соединений и солей органических кислот. М., 1977.7 с.

Поступило в редакицюю 7 декабря 2015 г.

После переработки 27 января 2016 г. 
Bikchantaev I.T. ${ }^{1}$, Shakirov Sh.K. ${ }^{l}$, Yagund E.M. ${ }^{2}{ }^{*}$, Yakhin R.G. ${ }^{2}$ ANALYSIS OF CHANGES IN IR SPECTRA OF WINTER RYE EXPOSED VARIOUS TYPES OF HYDROTHERMAL PROCESSING

${ }^{I}$ Tatar Research Institute of Agriculture, Orenburgski tract, 48, Kazan, 420059, (Russia)

${ }^{2}$ Kazan State University of Architecture and Engineering, ul. Zelenaya, 1, Kazan, 420043, (Russia),

e-mail:yagund1962@mail.ru

By the method of Fourier IR spectroscopy in the middle area carried out a qualitative analysis of the processes taking place in different types of hydrothermal processing of winter rye: extrusion, fermenting, roasting undertaken to increase the nutritional value of grain. Revealed absorption bands which can judge the moisture content of grain, as well as on the content of protein, fiber and starch. It is found that depending on the type of processing changes in the IR spectra associated with replacements of protein or carbohydrate macromolecules. It was shown that the fermentation of all samples is hydrolyzed macromolecular carbohydrates (cellulose and starch) and conversion of these compounds into carbohydrates of lower molecular weight . Extrusion, cooking and frying rye is denatured vegetable protein and carbohydrate portion remains generally unchanged. However, under any scenario hydrothermal processing of grain in it there are complex biochemical processes that result in a change of the biochemical and physical properties of the grain and its nutritional value.

Keywords: winter rye, hydrothermal processing, vegetable protein, sturch, FTIR Method

\section{References}

1. Sisuev V.A. Dostigeniya nauki i techniki v APK, 2013, no. 6, pp. 8-11. (in Russ.).

2. Fitsev A.I., Kosolapov V.M. Foodproduction, 2007, no. 1, pp. 27-30.

3. Taranov M.T., Sabirov A.H. Biokhimiya kormov. [Biochemistry feed]. Moscow, 1987, 224 p. (in Russ.).

4. Afanasiev V.A. Teoriya i practika specialnoi obrabotki zernovih komponentov v tecknologii kombikormov. [Theory and practice of special treatment of grain components in animal feed technology]. Voronezh, 2002, 296 p. (in Russ.).

5. Ovsyannikov A.I. Osnovi opitnogo dela v givotnovodstve. [Basics of experimental work in animal husbandry]. Moscow, 1976, 304 p. (in Russ.).

6. Kalashnikov A.P. Normi i racioni kormleniya celskokhozyaistvennih zhivotnih. [Standards and ration feeding farm animals. A Reference guide]. Moscow, 2003, 456 p. (in Russ.).

7. Len T.M. Zhivotnovodstvo, 2005, no. 7, pp.23-29. (in Russ.).

8. Kristchenko V.P. Blizhniya infrakrasnaya spectroskopiya. [Near infrared spectroscopy]. Moscow, 1997, 638 p. (in Russ.).

9. Morenko V.V., Khizhan E.I., Khizhan A.I. Vestnik Donetskogo nacionalnogo Universiteta. Ser. A, 2011, no. 2, pp.120-123. (in Russ.).

10. Sbornik dokladov 10 mezhdunarodnoi konferencii "Maslozhirovaya industriya 2010". [Proceedings of the 10th International Conference "Oilseed Industry 2010"]. St. Petersburg, 2010, pp. 96-98. (in Russ.).

11. Koteneva I.V., Sidorov V.I., Kotlyarova A.I. Himija rastitel'nogo syr'ja, 2011, no. 1, pp. 21-24. (in Russ.).

12. Zhbankov R.G. Infrakrasnie spectri i structura uglevodov. [Infrared spectra and structure of carbohydrates]. Minsk, 1972, 298 p. (in Russ.).

13. Zhbankov R.G. Infrakrasnie spectri cellulosi i eyi proizvodnih. [Infrared spectra of cellulose and its derivatives]. Minsk, 1964, 108 p. (in Russ.).

14. Gusev S.S., Soon Toon, Ermolenko I.N., Rogovin Z.A. Vysokomolekuljarnye soedinenija, 1961, vol. 3, no. 11, pp. 1684-1687. (in Russ.).

15. Gasanova E.S., Myazin N.G., Fominih T.O. Vestnik voronezhskogo agrarnogo universiteta, 2014, no. 1-2, pp. 14-19. (in Russ.).

16. Muhamadeeva R.M., Zhbankov R.G., Sopin V.F., Marchenko G.N. Uspehi Khimii, 1993, vol. 62, no. 4, pp. $351-364$. (in Russ.).

17. Korolevich M.V., Kirillova S.G., Piottuh-Peleckii V.N., Andrianov V.M. Zhurnal Structurnoi Khimii, 2009, vol. 50, no. 1, pp. 47-57. (in Russ.).

18. Gensh K.V., Kolosov P.V., Bazarnova N.G. Himija rastitel'nogo syr'ja, 2010, no. 1, pp. 63-66. (in Russ.).

19. Sivchik V.V., Zhankov R.G. Zhurnal prikladnoi spectroskopii, 1978, vol. 28, no. 6, pp. 1038-1045. (in Russ.).

20. Enciklopediya Polymerov. [Encyclopedia of polymer]. Moscow, 1977, vol. 3, pp. 853-860. (in Russ.).

21. GOST 17444-76. Reaktivy. Metody opredelenija osnovnogo veshhestva azotsoderzhashhih organicheskih soedinenij $i$ solej organicheskih kislot. [GOST 17444-76. Reagents. Methods for determination of basic nitrogen-containing organic substances Connecttions and salts of organic acids]. Moscow, 1977, 7 p. (in Russ.).

Received December 7, 2015

Revised January 27, 2016

\footnotetext{
* Corresponding author.
} 
